\title{
Cancer survival in Estonian migrants to Sweden
}

Bo Nilsson, Evi Gustavson-Kadaka, Timo Hakulinen, Tiiu Aareleid, Mati Rahu, Tadeusz Dyba, Samuel Rotstein

\begin{abstract}
Objective-To quantify the eventual extra loss of life incurred to cancer patients in Estonia compared with those in Sweden that was possibly attributable to differences in society.
\end{abstract}

Design-Population based survival of cancer patients in Estonia was compared with that of Estonian immigrants to Sweden and that of all cancer patients in Sweden. The cancer sites studied were female breast and ovary, male lung and prostate, and male and female stomach and colon. Setting-Data on incident cases of cancer were obtained from the population based Swedish and Estonian cancer registries. Participants-Data from Estonian patients in Sweden, Estonian patients in Estonia, and patients from the total Swedish population were included in the study. Main results-Differences in survival among the three populations, controlling for follow up time and age at diagnosis, were observed in breast, colon, lung, ovarian, and prostate cancers. The survival rates of Estonians living in Sweden and the total population of Sweden were better than that of the Estonians living in Estonia. For cancers of the breast and prostate, the excess mortality in the older age group ( 75 and above) was much greater in Estonia than in the other populations. Conclusions-Most differences in cancer survival between the Estonian and Swedish populations studied could be attributed to a longer delay in diagnosis, and also to inferior treatment (including access to treatment) in Estonia compared with Sweden. Estonia's lag in socioeconomic development, particularly in its public health organisation and funding, is probably the main source of the differences observed.

(f Epidemiol Community Health 1997;51:418-423)

We compared cancer survival in the population of Estonians who emigrated to (in fact, took refuge in) Sweden in 1944-45 with that in the total Swedish population and with that in the Estonian population in Estonia. It has been reported ${ }^{2}$ that breast cancer is diagnosed in advanced stages more often in Estonia than in Finland, which suggests that diagnostic delay is longer in Estonia than in Finland. Assuming the same is true for Estonia and Sweden, and that the treatment of cancer is inferior in Estonia to that in Sweden, it can be expected that survival will be higher for Estonian patients living in Sweden than those living in Estonia.
In addition, survival of Estonian patients living in Sweden will be similar to that of all patients in Sweden.

\section{Methods}

Data on incident cases of cancer were obtained from the Swedish Cancer Registry ${ }^{3}$ for the Swedish residents (patients diagnosed 197486) and from the Estonian Cancer Registry 4 for the Estonian residents (patients diagnosed 1979-85). Both registries are population based and cover the entire country. The sites studied were stomach and colon, female breast and ovary, and male lung and prostate. For the Estonians in Sweden and the Estonians in Estonia, all cases for all six sites were included in the analysis. For the total Swedish population, every fifth case for each site was included, except for ovarian cancer where every second case was included.

Each cancer patient was followed up for death through death certification, obtained in Sweden from the National Bureau of Statistics (NBS) death register, and in Estonia from the State Statistical Office. The follow up ended either with the death of the patient, or on December 31, 1988 for Estonians in Sweden, on December 31, 1989 for the Estonians in Estonia, and on December 31, 1991 for the Swedish population. The numbers of patients lost to follow up during the first five years were 58 for Estonians in Sweden, nine for Estonians in Estonia, and 39 patients from the total Swedish population. For these patients, the date of the last contact was used as the end of follow up. The cancer cases based on autopsy or death certificate only were excluded from the analyses.

Relative survival was analysed using a computer program package for cancer survival studies. ${ }^{5}$ The relative survival rate is the ratio of the observed to the expected survival in a comparable general population, taking into account population, age, sex, and calendar period. ${ }^{6}$ The excess mortality rate is 1 -the relative survival rate. We have used here the annual excess mortality rates (after diagnosis):

- Excess mortality rate (EMR) year $1=1$ minus the cumulative relative survival rate (CRSR) year $1\left(\mathrm{EMR}_{1}=1-\mathrm{CRSR}_{1}\right)$.

- For years 2 to 5 the $\mathrm{EMR}_{\mathrm{i}+1}=$ $\left(\mathrm{CRSR}_{\mathrm{i}}-\mathrm{CRSR}_{\mathrm{i}+1}\right) / \mathrm{CRSR}_{\mathrm{i}}, \quad \mathrm{i}=1,2,3,4,5$ years.

The expected survival probabilities for the Estonians in Sweden and for the total Swedish population were provided by the NBS, and values for the Estonians in Estonia by the 
Table 1 Number of patients at the beginning of follow up and number of deaths during the first five years of follow up in the total Swedish population (cancer diagnosed 1974-86), in Estonians in Sweden (cancer diagnosed 1974-86), and in Estonians in Estonia (cancer diagnosed 1979-85) in relation to site, age group, and sex

\begin{tabular}{|c|c|c|c|c|c|c|c|}
\hline \multirow[t]{2}{*}{ Site } & \multirow[t]{2}{*}{ Age (y) } & \multicolumn{2}{|c|}{$\begin{array}{l}\text { General Swedish } \\
\text { population }\end{array}$} & \multicolumn{2}{|c|}{$\begin{array}{l}\text { Estonian migrants } \\
\text { in Sweden }\end{array}$} & \multicolumn{2}{|c|}{$\begin{array}{l}\text { Estonians in } \\
\text { Estonia }\end{array}$} \\
\hline & & $\begin{array}{l}\text { No of } \\
\text { cases }\end{array}$ & $\begin{array}{l}\text { No of } \\
\text { deaths }\end{array}$ & $\begin{array}{l}\text { No of } \\
\text { cases }\end{array}$ & $\begin{array}{l}\text { No of } \\
\text { deaths }\end{array}$ & $\begin{array}{l}\text { No of } \\
\text { cases }\end{array}$ & $\begin{array}{l}\text { No of } \\
\text { deaths }\end{array}$ \\
\hline Female breast & $\begin{array}{c}-44 \\
45-64 \\
65-74 \\
75+ \\
\text { Total }\end{array}$ & $\begin{array}{r}933 \\
3814 \\
2656 \\
2705 \\
10108\end{array}$ & $\begin{array}{r}237 \\
1033 \\
861 \\
1511 \\
3642\end{array}$ & $\begin{array}{r}14 \\
56 \\
36 \\
34 \\
142\end{array}$ & $\begin{array}{r}1 \\
15 \\
15 \\
17 \\
48\end{array}$ & $\begin{array}{r}278 \\
845 \\
372 \\
258 \\
1753\end{array}$ & $\begin{array}{l}109 \\
349 \\
186 \\
182 \\
826\end{array}$ \\
\hline Male stomach & $\begin{array}{c}-44 \\
45-64 \\
65-74 \\
75+ \\
\text { Total }\end{array}$ & $\begin{array}{r}38 \\
591 \\
993 \\
1127 \\
2749\end{array}$ & $\begin{array}{r}31 \\
486 \\
891 \\
1061 \\
2469\end{array}$ & $\begin{array}{r}1 \\
27 \\
29 \\
31 \\
88\end{array}$ & $\begin{array}{l}- \\
19 \\
26 \\
30 \\
75\end{array}$ & $\begin{array}{r}69 \\
525 \\
436 \\
278 \\
1308\end{array}$ & $\begin{array}{r}51 \\
443 \\
394 \\
264 \\
1152\end{array}$ \\
\hline Female stomach & $\begin{array}{c}-44 \\
45-64 \\
65-74 \\
75+ \\
\text { Total }\end{array}$ & $\begin{array}{r}50 \\
311 \\
474 \\
918 \\
1753\end{array}$ & $\begin{array}{r}44 \\
265 \\
404 \\
851 \\
1564\end{array}$ & $\begin{array}{r}4 \\
11 \\
17 \\
36 \\
68\end{array}$ & $\begin{array}{r}4 \\
8 \\
13 \\
34 \\
59\end{array}$ & $\begin{array}{r}63 \\
322 \\
384 \\
360 \\
1129\end{array}$ & $\begin{array}{r}55 \\
262 \\
335 \\
343 \\
995\end{array}$ \\
\hline Male colon & $\begin{array}{c}-44 \\
45-64 \\
65-74 \\
75+ \\
\text { Total }\end{array}$ & $\begin{array}{r}81 \\
685 \\
1010 \\
1225 \\
3001\end{array}$ & $\begin{array}{r}32 \\
402 \\
664 \\
1008 \\
2106\end{array}$ & $\begin{array}{l}- \\
24 \\
23 \\
30 \\
77\end{array}$ & $\begin{array}{l}- \\
14 \\
11 \\
26 \\
51\end{array}$ & $\begin{array}{r}20 \\
133 \\
119 \\
95 \\
367\end{array}$ & $\begin{array}{r}13 \\
80 \\
96 \\
87 \\
276\end{array}$ \\
\hline Female colon & $\begin{array}{c}-44 \\
45-64 \\
65-74 \\
75+ \\
\text { Total }\end{array}$ & $\begin{array}{r}139 \\
723 \\
980 \\
1541 \\
3383\end{array}$ & $\begin{array}{r}45 \\
375 \\
558 \\
1166 \\
2144\end{array}$ & $\begin{array}{r}1 \\
16 \\
29 \\
49 \\
95\end{array}$ & $\begin{array}{l}-10 \\
16 \\
42 \\
68\end{array}$ & $\begin{array}{r}34 \\
193 \\
213 \\
169 \\
609\end{array}$ & $\begin{array}{r}20 \\
118 \\
141 \\
141 \\
420\end{array}$ \\
\hline Male lung & $\begin{array}{c}-44 \\
45-64 \\
65-74 \\
75+ \\
\text { Total }\end{array}$ & $\begin{array}{r}76 \\
1301 \\
1695 \\
1233 \\
4305\end{array}$ & $\begin{array}{r}68 \\
1166 \\
1588 \\
1219 \\
4041\end{array}$ & $\begin{array}{r}3 \\
43 \\
47 \\
38 \\
131\end{array}$ & $\begin{array}{r}3 \\
37 \\
47 \\
38 \\
125\end{array}$ & $\begin{array}{r}78 \\
1025 \\
714 \\
335 \\
2152\end{array}$ & $\begin{array}{r}69 \\
959 \\
701 \\
330 \\
2059\end{array}$ \\
\hline Ovary & $\begin{array}{c}-44 \\
45-64 \\
65-74 \\
75+ \\
\text { Total }\end{array}$ & $\begin{array}{r}613 \\
2555 \\
1603 \\
1237 \\
6008\end{array}$ & $\begin{array}{r}194 \\
1497 \\
1173 \\
1065 \\
3229\end{array}$ & $\begin{array}{r}3 \\
15 \\
12 \\
12 \\
42\end{array}$ & $\begin{array}{r}- \\
8 \\
8 \\
12 \\
28\end{array}$ & $\begin{array}{r}73 \\
327 \\
208 \\
143 \\
751\end{array}$ & $\begin{array}{r}33 \\
237 \\
181 \\
131 \\
582\end{array}$ \\
\hline Prostate & $\begin{array}{c}-44 \\
45-64 \\
65-74 \\
75+ \\
\text { Total }\end{array}$ & $\begin{array}{r}3 \\
1160 \\
3426 \\
4543 \\
9132\end{array}$ & $\begin{array}{r}3 \\
544 \\
1855 \\
3317 \\
5719\end{array}$ & $\begin{array}{r}- \\
55 \\
70 \\
38 \\
163\end{array}$ & $\begin{array}{l}- \\
14 \\
34 \\
24 \\
72\end{array}$ & $\begin{array}{r}2 \\
133 \\
341 \\
246 \\
722\end{array}$ & $\begin{array}{r}2 \\
87 \\
250 \\
209 \\
548\end{array}$ \\
\hline
\end{tabular}

Table 2 The five year observed and relative survival rates (\%) of patients from the total Swedish population (cancer diagnosed 1974-86), Estonians in Sweden (cancer diagnosed 1974-86), and Estonians in Estonia (cancer diagnosed 1979-85) in relation to site and sex

\begin{tabular}{|c|c|c|c|c|c|c|c|}
\hline \multirow[t]{2}{*}{ Site } & \multirow[t]{2}{*}{ Sex } & \multicolumn{2}{|c|}{$\begin{array}{l}\text { General Swedish } \\
\text { population }\end{array}$} & \multicolumn{2}{|c|}{$\begin{array}{l}\text { Estonian migrants } \\
\text { in Sweden }\end{array}$} & \multicolumn{2}{|c|}{$\begin{array}{l}\text { Estonians in } \\
\text { Estonia }\end{array}$} \\
\hline & & Observed & Relative & Observed & Relative & Observed & Relative \\
\hline \multirow{3}{*}{$\begin{array}{l}\text { Breast } \\
\text { Stomach }\end{array}$} & Female & 63.9 & 75.0 & 63.4 & 73.6 & 52.4 & 58.0 \\
\hline & Male & 10.1 & 12.8 & 14.5 & 19.4 & 11.8 & 14.8 \\
\hline & Female & 10.7 & 16.5 & 12.4 & 17.1 & 11.8 & 13.8 \\
\hline \multirow{2}{*}{ Colon } & Male & 29.7 & 37.5 & 31.8 & 43.2 & 24.4 & 30.9 \\
\hline & Female & 36.6 & 53.2 & 27.9 & 38.0 & 30.9 & 36.3 \\
\hline \multirow{3}{*}{$\begin{array}{l}\text { Lung } \\
\text { Ovary } \\
\text { Prostate }\end{array}$} & Male & 6.0 & 7.2 & 4.6 & 6.0 & 4.2 & 5.2 \\
\hline & Female & 34.5 & 39.3 & 34.9 & 40.8 & 22.4 & 24.7 \\
\hline & Male & 37.3 & 56.1 & 52.7 & 61.8 & 23.5 & 34.2 \\
\hline
\end{tabular}

Estonian Inter-University Population Research Center.

Regression analyses of the hazard functions, (excess mortality functions), as developed by Hakulinen and Tenkanen, ${ }^{7}$ were performed using GLIM software. ${ }^{8}$ Categorical background factors studied were: follow up time (FU) in years $(1,2,3,4,5)$, age in years $(0-44,45-64$, $65-74,75+$ ), sex (male, female), and population (Estonians in Sweden, Estonians in Estonia, and the total population of Sweden). Interactions between these variables were also considered. Only significant terms were included in the models.

Additional comparisons between survival among "high" $(75+$ years $)$ and "low" $(\leqslant 74$

\section{KEY POINTS}

- Estonians living in Sweden and the general population of Sweden had higher cancer survival rates than Estonians living in Estonia.

- Differences in cancer survival between countries are largely related to the level of socioeconomic development.

years) age patients were carried out for cancer at the different sites studied on model based fitted relative survival rates of the patients. Age standardisation of the model based relative survival rates for the age group 0-74 years was carried out for each cancer site and sex separately by the direct method, using the age distribution of the Estonian residents of Sweden as a standard. Excess or deficit in (excess) mortality for older compared with younger age was calculated on fitted values by the formula:

1 -(relative survival rate (high age)/relative survival rate (low age)).

This quantity will be referred to as the relative excess mortality due to high age.

\section{Results}

The final analysis included data from the 40439 patients from the total Swedish population, the 806 Estonian patients living in Sweden, and the 8791 Estonian patients living in Estonia. The number of patients at the beginning of follow up and the number of deaths during the first five years in relation to age group for each cancer site studied are presented in table 1 . Almost all observed and relative five year survival rates in relation to site and sex were lower for the Estonian patients in Estonia than for the Estonian patients in Sweden and the patients from the total Swedish population (table 2). The exceptions were stomach and female colon cancers. The Swedish patients were, however, on average, older than the Estonian patients and no age standardisation was carried out here.

BREAST CANCER

For female breast cancer, all categorical factors, including population category, were significant in the fitted model (table 3 ) - the relative survival being lower in Estonia compared with Sweden. Adding an interaction term between the follow up year and age also showed a significant reduction in deviance. After four years of follow up, the excess mortality still differed between the Estonians in Estonia and the two other populations (fig 1) (Estonian patients in Sweden and patients from the total Swedish population represented by the same line). Excess mortality prevailed in all three populations during the five years of follow up. The relative survival rates were lower in Estonia than in Sweden. In both Estonia and Sweden, the relative survival rates were lower for the high age group $(75+$ years) than for the low 


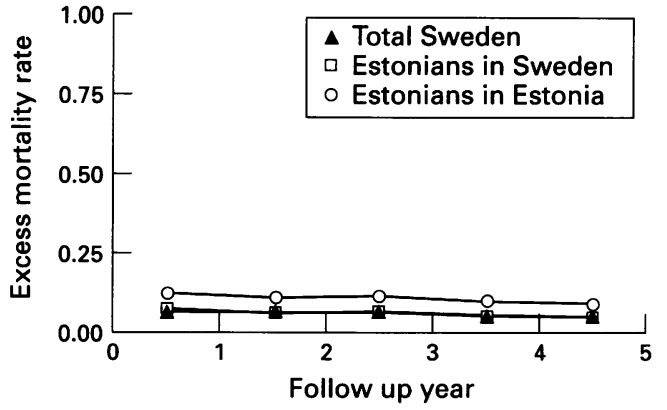

Figure 1 Excess mortality in female breast cancer patients from the total Swedish population (cancer diagnosed 1974-86), Estonians in Sweden (cancer diagnosed 1974-86) and Estonians in Estonia (cancer diagnosed 1979-85), in relation to follow up year after diagnosis.

Table 3 Variables included in the finally chosen relative survival models in relation to site and sex

\begin{tabular}{lllll}
\hline Site & Sex & Terms* & Pearson's $\chi^{2}$ & $d f$ \\
\hline Breast & Female & 1, F, A, C, F. A & 37.5 & 38 \\
Stomach & Male & 1, F, A, C, F. A & 37.6 & 38 \\
Stomach & Female & 1, F, A, C, F. A & 36.2 & 35 \\
Colon & Male & 1, F, A, C, F. A, C. A & 29.8 & 28 \\
Colon & Female & 1, F, A, C, F. A & 37.2 & 38 \\
Lung & Male & 1, F, A, C, C. A, C. F & 21.3 & 28 \\
Ovary & Female & 1, F, A, C, F. A & 30.4 & 38 \\
Prostate & Male & 1, F, A, C, F. A & 29.1 & 28 \\
\hline
\end{tabular}

${ }^{*} 1$ : constant; F: first five follow up years, categorical; A: age 4 (4 age groups), categorical; C: population ( 3 groups), categorical; interaction between variables.

Table 4 Model based fitted relative survival rates of patients from the total Swedish population (cancer diagnosed 1974-86), Estonians in Sweden (cancer diagnosed 1974-86), and Estonians in Estonia (cancer diagnosed 1979-85) in relation to site, age group, sex, and year of follow up (1 and 5)

\begin{tabular}{|c|c|c|c|c|c|}
\hline \multirow[t]{2}{*}{ Site } & \multirow{2}{*}{$\begin{array}{l}\text { Follow } \\
\text { up }\end{array}$} & \multirow{2}{*}{$\begin{array}{l}\text { Age } \\
(y)\end{array}$} & \multicolumn{3}{|c|}{ Relative survival, \% age standardised } \\
\hline & & & $\begin{array}{l}\text { General Swedish } \\
\text { population }\end{array}$ & $\begin{array}{l}\text { Estonian migrants } \\
\text { in Sweden }\end{array}$ & $\begin{array}{l}\text { Estonians } \\
\text { in Estonia }\end{array}$ \\
\hline \multirow[t]{3}{*}{ Female breast } & 1 & $\begin{array}{l}-74 \\
75\end{array}$ & $\begin{array}{l}95.0 \\
88.7\end{array}$ & $\begin{array}{l}94.7 \\
88.2\end{array}$ & $\begin{array}{l}90.5 \\
79.4\end{array}$ \\
\hline & 5 & -74 & 75.8 & 74.8 & 58.6 \\
\hline & & $75+$ & 71.1 & 69.9 & 51.8 \\
\hline \multirow[t]{4}{*}{ Male stomach } & 1 & -74 & 36.4 & 39.7 & 34.7 \\
\hline & & $75+$ & 23.9 & 27.0 & 22.3 \\
\hline & 5 & -74 & 18.6 & 21.5 & 14.9 \\
\hline & & $75+$ & 10.6 & 12.7 & 9.4 \\
\hline \multirow{4}{*}{ Female stomach } & 1 & -74 & 39.1 & 42.2 & 38.4 \\
\hline & & $75+$ & 23.0 & 26.0 & 22.5 \\
\hline & 5 & -74 & 15.1 & 17.7 & 14.6 \\
\hline & & $75+$ & 10.2 & 12.3 & 9.8 \\
\hline \multirow{4}{*}{ Male colon } & 1 & -74 & 73.8 & 72.6 & 56.1 \\
\hline & & $75+$ & 53.9 & 52.3 & 30.8 \\
\hline & 5 & -74 & 50.2 & 54.1 & 33.4 \\
\hline & & $75+$ & 33.7 & 31.8 & 12.6 \\
\hline \multirow[t]{4}{*}{ Female colon } & 1 & -74 & 71.0 & 64.7 & 60.2 \\
\hline & & $75+$ & 51.7 & 43.2 & 37.5 \\
\hline & 5 & -74 & 51.1 & 42.6 & 36.9 \\
\hline & & $75+$ & 39.1 & 30.3 & 24.8 \\
\hline \multirow[t]{4}{*}{ Male lung } & 1 & -74 & 30.2 & 38.9 & 27.2 \\
\hline & & $75+$ & 13.4 & 15.9 & 26.6 \\
\hline & 5 & -74 & 10.2 & 12.4 & 6.7 \\
\hline & & $75+$ & 1.6 & 0.2 & 4.4 \\
\hline \multirow{4}{*}{ Ovary } & 1 & -74 & 68.4 & 67.3 & 57.1 \\
\hline & & $75+$ & 38.0 & 36.4 & 23.8 \\
\hline & 5 & -74 & 47.5 & 56.3 & 34.2 \\
\hline & & $75+$ & 22.2 & 20.3 & 10.4 \\
\hline \multirow[t]{3}{*}{ Prostate } & 1 & -74 & 84.9 & 89.3 & 73.9 \\
\hline & & $75+$ & 73.8 & 80.3 & 55.6 \\
\hline & 5 & $\begin{array}{l}-74 \\
75+\end{array}$ & 55.6 & $\begin{array}{l}67.7 \\
55.0\end{array}$ & 31.8 \\
\hline
\end{tabular}

Table 5 Surgical treatment of female breast cancer diagnosed in Sweden and Estonia in 1979-85 in relation to age groups 75 years and less and 76 years and more

\begin{tabular}{|c|c|c|c|c|c|c|}
\hline \multirow[t]{2}{*}{ Age (y) } & \multicolumn{3}{|c|}{ Sweden } & \multicolumn{3}{|c|}{ Estonia } \\
\hline & $\begin{array}{l}\text { No of } \\
\text { cases }\end{array}$ & $\begin{array}{l}\text { No operated } \\
\text { on }\end{array}$ & $\%$ & $\begin{array}{l}\text { No of } \\
\text { cases }\end{array}$ & $\begin{array}{l}\text { No operated } \\
\text { on }\end{array}$ & $\%$ \\
\hline $\begin{array}{r}-75 \\
76+\end{array}$ & $\begin{array}{l}4787 \\
1203\end{array}$ & $\begin{array}{r}4365 \\
821\end{array}$ & $\begin{array}{l}91.2 \\
68.2\end{array}$ & $\begin{array}{r}1525 \\
224\end{array}$ & $\begin{array}{r}1005 \\
124\end{array}$ & $\begin{array}{l}65.9 \\
55.4\end{array}$ \\
\hline Total & 5990 & 5186 & 86.6 & 1749 & 1129 & 64.5 \\
\hline
\end{tabular}

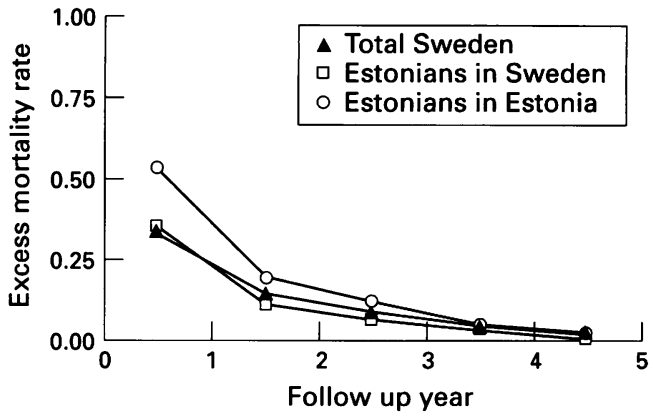

Figure 2 Excess mortality in male colon cancer patients from the total Swedish population (cancer diagnosed 1974-86), Estonians in Sweden (cancer diagnosed 1974-1986), and Estonians in Estonia (cancer diagnosed 1979-85) in relation to follow up year after diagnosis.

age group ( $\leqslant 74$ years) (table 4$)$. The relative excess mortality due to high age was much greater in the Estonians in Estonia compared with the Estonians in Sweden and the total population of Sweden-11.6\% v $6.6 \%$ after five years. Surgical treatment in female breast cancer patients was more common (according to what was recorded in the cancer registries of Stockholm and Estonia) in Sweden (86.6\%) compared with Estonia (64.5\%), during 19791985 (table 5). In patients below the age of 7 years, the difference in percentages between the countries was 25.3 , while for older patients (76+ years) it was 12.8 .

\section{STOMACH CANCER}

For stomach cancer, among men and women, the categorical factors included in the model were follow up, age, population category, and an interaction between follow up and age; population, however, was not significant (table $3)$. Very little difference in excess mortality between the populations could be detected during the five years of follow up. Comparatively small excess mortality could be detected after three to four years of follow up in the populations. Relative survival rates differed for low and for high age patients between the populations (table 4). No differences in excess mortality rates due to high age could be detected between the populations studied.

\section{COLON CANCER}

For colon cancer, in men and women, a difference between populations was observed and also an effect of age and year of follow up, an interaction effect between follow up and age, and, for men, an interaction between age and population category (table 3 ). No difference in excess mortality between the populations was seen after the second follow up year (figs 2 and 3 ). After four years of follow up, comparatively little excess mortality could be detected in the populations studied. The relative survival of male and female patients in relation to age group was lower for the Estonians in Estonia than the Estonians in Sweden or the total Swedish population (table 4 ). The excess mortality rates due to high age were greater in Estonia than in Sweden. 


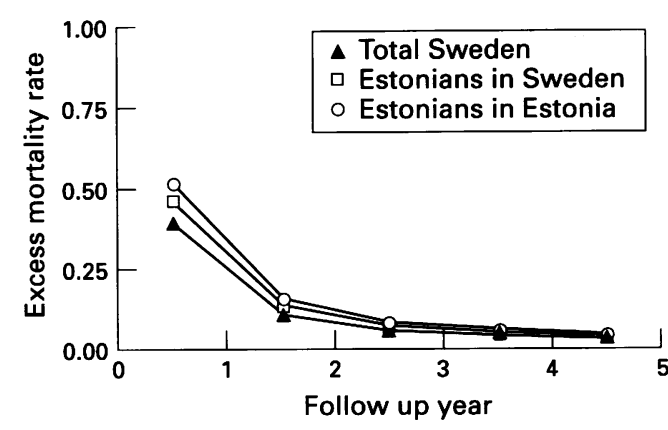

Figure 3 Excess mortality in female colon cancer patients from the total Swedish population (cancer diagnosed 1974-86), Estonians in Sweden (cancer diagnosed 1974-86), and Estonians in Estonia (cancer diagnosed 1979-85), in relation to follow up year after diagnosis.

\section{LUNG CANCER}

The fitted model for lung cancer in men included follow up year, age, population, an interaction term between age and population category, and follow up and population category (table 3 ). Excess mortality could be detected in the populations mainly before the fourth year of follow up. There was a higher relative survival in low age groups for the Estonians in Sweden and the total Swedish patients than for Estonians in Estonia (table 4). In the high age group, on the other hand, there was a somewhat higher survival in Estonia than in Sweden. The excess high age mortality during the first year of follow up was much higher in the Estonians in Sweden (59.1\%) and in the total Swedish population (56.3\%) than in the Estonians in Estonia (2.2\%).

\section{OVARIAN CANCER}

The fitted model for ovarian cancer included follow up year, age, population category, and an interaction term between follow up and age (table 3). Differences in excess mortality between the populations could be seen mainly during the first three years of follow up. Excess mortality could also be detected in the populations mainly during the first years of follow up. Relative survival was higher in Estonians in Sweden and in the total population in Sweden for both the low and the high age patients compared with the Estonians in Estonia (table 4). The excess high age mortality at five years was somewhat higher among the Estonians in Estonia (69.6\%) than in the Estonians in Sweden (63.9\%) and the total Swedish population $(53.3 \%)$.

\section{PROSTATE CANCER}

For prostate cancer, the factors in the fitted model were follow up year, age, population category, and an interaction term between follow up and age (table 3 ). Differences in excess mortality between the populations prevailed during the five years of follow up (fig 4). Excess mortality in the patient groups persisted during the five years of follow up. The relative survival rates were much higher for the Estonians in Sweden than for the Estonians in Estonia (table 4). The excess mortality in high age patients

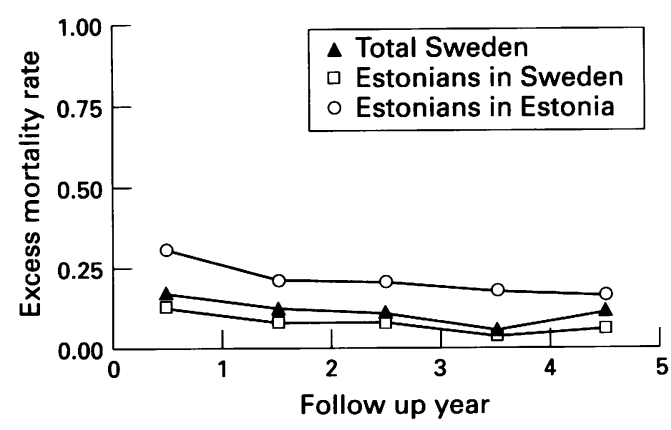

Figure 4 Excess mortality in prostate cancer patients from the total Swedish population (cancer diagnosed 1974-86), Estonians in Sweden (cancer diagnosed 1974-86), and Estonians in Estonia (cancer diagnosed 1979-85) in relation to follow up year after diagnosis.

was greater in the Estonians in Estonia (36.5\%), compared with the Estonians in Sweden $(18.8 \%)$, and the total Swedish population $(23.2 \%)$.

\section{Discussion}

With regard to relative survival, no substantial differences were found between the Estonians living in Sweden and the total Swedish population. The size of the migrant population studied was, however, rather small compared with the other two populations. Considerable differences were found between the Estonians in Estonia and the other two populations.

Cancer survival data have become increasingly available for international comparisons during the past decade. At the same time, there have been warnings regarding the interpretation of the differences between survival rates. ${ }^{910}$ These are related to the comparability of the incident cases of cancer included in survival analyses, and to specific factors that may affect the survival rates of patients.

In Sweden and Estonia death certificates only cases (DCO) are not used to any extent in the cancer registration process, which excludes cases with a short survival after follow back procedures.

A major advantage of population based survival studies is the avoidance of selection bias, and the use of a relative survival rate provides a control for competing causes of death. ${ }^{6}$ In the present study, both approaches have been used. However, part of the differences in the survival pattern seen in the populations probably remain uncontrolled and cannot be exhaustively explained on the basis of the data used for the study. For example, no adjustment for the tumour stage could be carried out because the Estonian Cancer Registry, but not the Swedish Cancer Registry, collects information on stage.

For female breast cancer, our analysis showed higher relative survival rates for patients in Sweden than those in Estonia, and the difference was largest in the high age group. This is consistent with the findings from survival studies comparing Finland and Estonia, ${ }^{2}$ and the former GDR and Estonia. ${ }^{11}$ These data suggest that the diagnostic lag, particularly for 
elderly patients, was longer in Estonia than in Finland and the GDR (and probably also in Sweden). In Estonia the symptoms of breast cancer in older patients may be studied less intensively and/or older patients may seek medical assistance later than younger patients.

In 1979-85, the proportion of female breast cancer patients treated surgically was much smaller in Estonia than in Sweden. (According to what was recorded as surgical treatment in the cancer registries.) This difference was, however, not as great for patients aged 75 and above as it was in younger patients, suggesting that the treatment modality itself cannot be regarded as a cause of lower survival among high age patients in Estonia. The treatment differences are probably reflecting the differences in the stage of the disease, which is the main indicator of diagnostic delay. One cannot exclude underdiagnosis of slowly growing localised malignancies, which have a better prognosis, in Estonia, where there is no extensive mammographic screening programme. ${ }^{2}$ However, screening based on mammography has only a limited role in the high relative survival rates of breast cancer patients in Sweden, as it was mainly introduced after 1986, the last year included in the Swedish incident data for this study. ${ }^{12}$

For male and female stomach cancer patients, no difference in relative survival was detected between the populations studied over the follow up-neither in younger nor older patients. However, the proportion of histologically non-verified stomach cancer cases among patients aged 75 and over was much higher in Estonia than in Sweden, ${ }^{1}$ suggesting that there may be more non-malignant lesions in the Estonian population because of a lower level of diagnostic accuracy leading to misclassification.

For colon cancer, the patients among Estonians in Sweden and the total Swedish population experienced a higher relative survival compared with patients in Estonia, particularly during the first year of follow up. The treatment of colon cancer was mainly surgical during the period studied in both Sweden and Estonia, but the difference in stage distribution could be a factor leading to the differences in survival. As recently shown by the EUROCARE study, ${ }^{10}$ colon cancer patients in Estonia and Poland (Cracow) experienced much lower relative survival than most western Europe populations studied.

For male lung cancer patients, survival was higher among low age patients in Sweden than in Estonia. For elderly patients, however, the survival rates were somewhat higher in patients in Estonia, which may be a result of overtreatment of the lung cancer patients in Sweden. The difference in survival for high age patients was largest during the first year of follow up. This suggests that more elderly patients died soon after diagnosis in Sweden than in Estonia because of a higher surgery rate in Sweden in these patients. (Other possible, but not as likely, reasons for the difference could include different distribution of cell type and even later disease stage at diagnosis). This finding was unexpected and shows that comparisons between intensively and less in- $c$ tensively treated patient populations like those in Sweden and Estonia could be valuable.

The higher relative survival rate of the high age lung cancer patients in Estonia compared with those in Sweden cannot be considered a result of poor follow up. The patients' follow up in the Estonian cancer registry is a mixed type, including the updating of records from death certificates and direct contacts with the health care institutions. ${ }^{4}$ The relatively good quality of follow up in the Estonian cancer registry was shown recently by an international survival study. ${ }^{10}$ From a sample of 196 lung cancer patients considered alive five years after diagnosis, an error in determining life status was found in only $1.0 \%$, leading to a difference from the true five year observed survival rate of $0.1 \%$. But, again, as with stomach cancer, is one cannot exclude the possible role of a much smaller percentage of microscopically confirmed cases in Estonia than in Sweden. ${ }^{13}$

The ovarian cancer patients in Sweden showed better survival than those in Estonia. Overall, the relative survival was poorer for or high age patients than low age patients, while the excess mortality in the high age group was somewhat higher in Estonia. In prostate cancer, $\infty$ the patients in Sweden had better survival, $\subseteq$ whereas the excess high age mortality was much higher in Estonia than in Sweden. This finding suggests, as with breast cancer, that the diagnostic delay among patients aged 75 years and over was much longer in Estonia. Latent prostate cancer, as an additional finding in elderly men, is found more often in Sweden than in Estonia, perhaps because of differences in the frequency of transurethral resection for hyperplasia between countries. ${ }^{14}$ If this is true, then the number of patients with slowly developing tumours with a better prognosis may be much larger in Sweden.

Taken with the results of the previous study, we can conclude that:

- The Estonians in Estonia had lower cancer survival rates than Estonians in Sweden,

- The cancer survival rates are similar for Estonians in Sweden and the total Swedish population, and

- The cancer incidence in the Estonians who took refuge in Sweden in 1944-45 was intermediate in relation to that among Estonians in Estonia and the entire Swedish population.

Lower survival rates of cancer patients in the former Eastern Bloc countries compared with western countries is a common finding from recent survival comparisons. ${ }^{101516}$ On the other

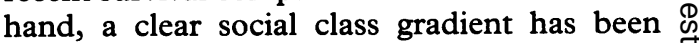
observed in cancer patients' survival in Sweden and Finland, the countries with declared fairly equal accessibility to health care. ${ }^{17-19}$ Among $\stackrel{\mathbb{D}}{\circ}$ possible explanations, diagnostic delay, differ- $\mathbb{D}$ ent treatment, and even the host resistance have been suggested.

Although there are many reasons underlying differences in cancer patients' survival between "rich" and "poor" countries, these are largely 
related to the community's wealth, and particularly, to the resources allocated to health care. Sweden, a country with a larger GDP than Estonia, also contributes a larger percentage of it to health care. In Sweden, health expenditure was $8.8 \%$ of GDP in $1990,{ }^{20}$ and in Estonia it was $2.5 \%$ of GDP in $1989 .{ }^{21}$ The big lag in socioeconomic development and public health organisation in Estonia may affect survival from a disease like cancer, and particularly in older patients who also experience a deficiency in social support.

Funding: the Cancer Society of Stockholm.

Conflicts of interest: none.

1 Nilsson B, Gustavson-Kadaka E, Rotstein S, Hakulinen T, Rahu M, Aareleid T. Cancer in Estonian migrants to Sweden. Int $\mathcal{F}$ Cancer 1993;55:190-95.

2 Karjalainen S, Aareleid T, Hakulinen T, Pukkala E, Rahu M, Tekkel $M$. Survival of female breast cancer patients in Finland and in Estonia: stage at diagnosis important determinant of the difference between countries. Soc Sci Med 1989;28:233-38.

3 National Board of Health and Welfare. The Cancer Registry. Cancer incidence in Sweden 1991. Helsingborg: Centre for Eancer incidence in Swiology, 1994.

Epidemiology, 1994.
4 Rahu M. Estonia. In: Parkin DM, Muir CS, Whelan SL, Gao YT, Ferlay J, Powell J eds. Cancer incidence in five continents. Vol VI. No 120. IARC Scientific Publications Lyon: IARC, 1992:569-73.

5 Hakulinen T, Abeywickrama K. A computer program package for relative survival analysis. Computer Programs in Biomedicine 1985;19:197-207.

6 Ederer F, Axtell LM, Cutler SJ. The relative survival rate:
A statistical methodology. National Cancer Institute MonoA statistical methodo $1961 ; 6: 101-21$

7 Hakulinen T, Tenkanen L. Regression analysis of relative survival rates. Appl Stat 1987;36:309-17.

8 Francis B, Green M, Payne CD eds. The generalized linear interactive modelling.system release 4 manual. Oxford: Clarendon Press, 1993.

9 Hakulinen T. A comparison of nationwide cancer survival statistics in Finland and Norway. World Health Stat $Q$ 1983;36:35-46.

10 Berrino F, Sant M, Verdecchia A, Capocaccia R, Hakulinen $T$, Estevé J eds. Survival of cancer patients in Europe. No 132. Lyon: IARC Scientific Publications, 1995.

11 Aareleid T, Staneczek W, Rahu M, Möhner M. On the background of differences in survival of female breast cancer patients in the German Democratic Republic and cancer patients in the German Democratic Rep

12 Törnberg S, Carstensen J, Hakulinen T, Lenner P, Hatschek $T$, Lundgren $B$. Evaluation of the effect on breast cancer
, mortality of population based mammography screening programmes. Fournal of Medical Screening 1994;1:184-87.

13 Parkin DM, Muir CS, Whelan SL, Gao YT, Ferlay J, Powell $\mathrm{J}$ eds. Cancer incidence in five continents. Vol VI. No 120. Lyon: IARC Scientific Publications, 1992.

14 Potosky AL, Kessler L, Gridley G, Brown CC, Horm JAW. Rise in prostatic cancer incidence associated with increased use of transurethral resection. $尹$ Natl Cancer Inst 1990;82:1624-28.

15 Pawlega J. Cancer incidence and survival in Alberta, Canada and Cracow, Poland. Chronic Diseases in Canada 1989;10: 86-7.

16 Aareleid T, Rahu M. Cancer survival in Estonia from 1978 to 1987. Cancer 1991;68:2088-92.

17 Vågerö D, Persson G. Cancer survival and social class in Sweden. $\mathcal{f}$ Epidemiol Community Health 1987;41:204-9. 18 Karjalainen S, Pukkala E. Social class as a prognostic factor in breast cancer survival. Cancer 1990;66:819-26.

19 Auvinen A. Social class and colon cancer survival in Finland. Cancer 1992;70:402-9.

20 The World Bank. The development report 1993: investing in health. New York: Oxford University Press, 1993.

21 The World Bank. Estonia: the transition to a market economy. $A$ World Bank country study. Washington: The World Bank, 1993. 